\title{
Closure of Earth's Biosphere: Evolution and Current State
}

\author{
Sergey I. Bartsev*a,b, \\ Andrey G. Degermendzhi ${ }^{a}$ and Antonina B. Sarangova ${ }^{b}$ \\ ${ }^{a}$ Institute of Biophysics SB RAS \\ FRC "Krasnoyarsk Science Center SB RAS" \\ 50/50 Akademgorodok, Krasnoyarsk, 660036, Russia \\ ${ }^{b}$ Siberian Federal University \\ 79 Svobodny, Krasnoyarsk, 660041, Russia
}

Received 27.02.2019, received in revised form 23.04.2019, accepted 06.06.2019

The existence of the biosphere is determined by the presence of a constant circulation of substances, carried out by a highly branched trophic network of mainly closed material loops. How this largely selfcontained system formed remains unclear. The theory of evolution cannot help answer this question since the closure of the biosphere is not an adaptive trait of an individual - this is the essence of the Vernadsky-Darwin paradox. The present paper discusses stages of the formation of the biosphere in the context of closure - a key property and parameter of the biosphere - and possible approaches to resolving the paradox. The authors assume that the appearance of the first living organisms did not mean the appearance of the biosphere as a system of interacting components. The formation of the biosphere in the true sense of the word was associated with the appearance of predation approximately 500 million years ago and the emergence of a highly branched trophic network. The authors obtain simple estimates showing that, on the one hand, living organisms are potentially capable of changing their environment at the global level in a negligible geological time period but, on the other hand, are capable of maintaining an accurate balance of global material cycling for several tens of thousands of years. A simple model was used to show the effect of stoichiometric constraints on the formation of closed material flow in simple ecosystems and to demonstrate the need for increased diversity at trophic levels to overcome these stoichiometric constraints.

Keywords: Vernadsky-Darwin paradox, biosphere origin, biosphere closure formation.

Citation: Bartsev S.I., Degermendzhi A.G., Sarangova A.B. Closure of Earth $\square$ s biosphere: evolution and current state. J. Sib. Fed. Univ. Biol., 2019, 12(3), 337-347. DOI: 10.17516/1997-1389-0307.

(C) Siberian Federal University. All rights reserved

This work is licensed under a Creative Commons Attribution-NonCommercial 4.0 International License (CC BY-NC 4.0).

* Corresponding author E-mail address: bartsev@yandex.ru

ORCID: 0000-0003-0140-4894 (Bartsev S.I.); 0000-0002-2218-3982 (Degermendzhi A.G.) 


\title{
Замкнутость земной биосферы:
}

эволюция и текущее состояние

\author{
С.И. Барцев ${ }^{\mathrm{a}, \boldsymbol{\sigma}}$, \\ А.Г. Дегерменджи ${ }^{\mathrm{a}}$, А.Б. Сарангова ${ }^{6}$ \\ ${ }^{a}$ Институт биофизики СО РАН \\ ФИЦ «Красноярский научный иентр СО РАН» \\ Россия, 660036, Красноярск, Академгородок, 50/50 \\ ${ }^{6}$ Сибирский федеральный университет \\ Россия, 660041, Красноярск, пр. Свободный, 79
}

Существование биосферы определяется наличием постоянного круговорота веществ, осуществляемого высокоразветвленной трофической сетью, с высокой степенью замкнутости вещественных потоков. Каким образом была сформирована столь согласованная система с высоким уровнем замкнутости, остается неясным. Простое обращение к теории эволюиии нам помочь не может, поскольку замкнутость биосферы не является приспособительным признаком особи - в этом суть парадокса Вернадского-Дарвина. В статье обсуждаются этапы формирования биосферы в контексте замкнутости - ключевого свойства и параметра биосферы, а также обсуждаются подходы к разрешению парадокса. Выдвинут тезис о том, что появление первых живых организмов не означает появления биосферы как системы взаимодействуюших компонентов. Говорить о биосфере в полном смысле этого слова можно после появления хищничества около 500 млн лет назад и возникновения разветвленной трофической сети. Приведены простые оценки, показывающие, что, с одной стороны, живые организмы потенциально способны изменить среду обитания на глобальном уровне за ничтожное по геологическим масштабам время. Но, с другой стороны, они десятки тысяч лет способны обеспечивать точный баланс глобального круговорота веществ. На простой модели показано влияние стехиометрических ограничений на возможность формирования замкнутого потока веществ в простых экосистемах и продемонстрирована необходимость увеличения разнообразия на трофических уровнях для преодоления этих стехиометрических ограничений.

Ключевые слова: парадокс Вернадского-Дарвина, происхождение биосферы, формирование замкнутости биосферы.

\section{Introduction}

The generally accepted broad definition of the biosphere as the zone of life on Earth is descriptive (morphological) and cannot explain the origin of its main property closure. To discuss the properties of the biosphere, it should be considered as a system consisting of certain elements (components) and interactions between them. A population of organisms represents a relatively homogeneous component of the biosphere. We consider one of the most important properties of the population, using a school task for illustration purposes. 


\section{Potential of living organisms: simple estimates}

Let one bacterium occupy a volume of approximately one cubic micrometer and divide into two identical cells every hour. After 35 hours, the offspring of one bacterium fill a one-liter jar. The question is as follows: How long does it take the bacteria to fill half the jar? The answer is almost obvious -34 hours.

We continue to solve the tasks. Suppose that an ancient bacterium on ancient Earth can feed on air (hardly an unrealistic assumption if it performs photosynthesis and the concentration of carbon dioxide in the atmosphere is high) and, similar to the bacterium from the previous task, it divides into two cells every hour. The question is as follows: After what time will the offspring of this bacterium cover the globe with a one-meter-thick layer? One can make rather simple calculations and find that the required time is approximately 86 hours, or 3.6 days. An additional question is as follows: After what time will the offspring cover the globe with a layer $10 \mathrm{~km}$ thick? The answer is approximately 100 hours, or slightly more than four days.

These simple examples illustrate the potential for living systems to reproduce in the absence of limiting factors. If there is no resource deficiency nor any other limitations, the results of the vital activity of living organisms will be evident at the global level instantaneously at a geological time scale. A self-replicating system without limitations very quickly consumes all the available resources of a finite, albeit arbitrarily large, volume and stops growing. The following question arises: How has life capable of consuming all available planetary resources in a short period of time managed to survive on Earth for 4 billion years? Find the answer in the following task.

\section{The carbon cycle}

The annual net primary production from photosynthesis of terrestrial vegetation is approximately $60 \mathrm{GtC}$; in other words, this amount of carbon is removed from Earth's atmosphere and transferred to biomass. The amount of terrestrial biomass is approximately $550 \mathrm{GtC}$, and the atmosphere contains approximately 750 GtC (Brovkin et al., 2004; IPCC, 2007; Stainforth et al., 2005). If we assume that the rate of photosynthesis is proportional to the concentration of carbon (carbon dioxide) in the atmosphere, then the equation describing the increase in biomass and, hence, the loss of carbon from the atmosphere can be written as:

$$
\frac{d X}{d t}=\mu\left[S_{0}-\gamma_{C}\left(X-X_{0}\right)\right] X
$$

where $\mu$ is the specific growth rate of plant biomass; $\gamma_{C}$ is a stoichiometric coefficient (in our case, it is close to 1); and $S_{0}$ and $X_{0}$ are the amount of carbon in the atmosphere and the biomass of land plants, respectively, at the beginning of our "experiment".

The solution to this equation is as follows:

$$
\begin{gathered}
X(t)=\frac{X_{0}\left(S_{0}+\gamma_{C} X_{0}\right) e^{\mu\left(S_{0}+\gamma_{C} X_{0}\right) t}}{\gamma_{C} X_{0} e^{\mu\left(S_{0}+\gamma_{C} X_{0}\right) t}+S_{0}}, \\
S(t)=S_{0}-\gamma_{C}\left(X(t)-X_{0}\right),
\end{gathered}
$$

Suppose that the process of photosynthesis is the only process that affects the composition of the atmosphere. It is easy to calculate how long it will take for plants to convert $99 \%$ of atmospheric carbon into their own biomass (for simplicity, we assume that plant growth is limited only by the concentration of carbon dioxide in the atmosphere). It turns out that plants can deplete atmospheric carbon dioxide, leaving merely $1 \%$ of its original level, in $\sim 60$ years - in no time at all at a geological scale. From this estimate, it becomes clear how precisely the countercurrent flow of $\mathrm{CO}_{2}$ (primarily from the soil) into the atmosphere must be coordinated to keep its concentration 
in the atmosphere at an almost constant level. Indeed, the atmospheric $\mathrm{CO}_{2}$ concentration deviated from its mean value ( $240 \mathrm{ppm})$ by no more than $20 \%$ over more than 400000 years, even under global climate change during the glacial periods (Petit et al., 1999).

At the same time, since the beginning of the Industrial Revolution in the $18^{\text {th }}$ century, the atmospheric $\mathrm{CO}_{2}$ concentration has been steadily increasing, and the biosphere cannot bring it back to its previous level. This indicates that the level reached during the development of the biosphere resulted from the adjustment of the components of the global carbon cycle in response to each other rather than a permanent mechanism capable of compensating for the flow of carbon from the outside.

\section{The closure of the biosphere and the Vernadsky-Darwin paradox}

These simple calculations clearly show that the key feature of the biosphere that ensures its long-term existence is the balance of the material cycles therein, which is termed "closure". In thermodynamics, a closed system is a system that exchanges only energy with the environment. Ecological closure, in addition to the absence of material exchange with the environment, suggests the presence of an internal material cycle carried out by living organisms.

In accordance with V.I. Vernadsky's ideas, life in Earth's biosphere can exist only because cyclic transformations of substances carried out by all living organisms using the energy of the Sun are largely closed loops. Whatever is produced by an organism, including itself, is consumed by other organisms, and the cycle continues. Thus, a continuous cyclic network of metabolic chemical transformations is established in the biosphere, and its functioning enables living organisms to use the same atoms of chemical elements repeatedly.
Here, we face a paradox, which was named the Vernadsky paradox by the authors (Barlow, Volk, 1990). The authors formulated it in the form of two questions: "How can an aggregate of opensystem life forms evolve and persist for billions of years within a global system that is largely closed to matter influx and outflow?" and "How do the inputs and outputs of myriad open systems form a life mesh in such a way that material closure as a boundary condition of the planet does not destroy the organized subsystems?"

If we accept that the current highly closed state of the biosphere, with which it entered the Industrial Revolution, is the result of its evolutionary and ecological development, then this paradox can be formulated as follows: "The closure of the biosphere is not an adaptive trait of an individual." Indeed, natural selection leads to the survival of an individual that captures more resources and leaves behind a larger number of viable offspring; in other words, natural selection leads to the success of an organism with an advantage that provides gains here and now. The consequences of breaking the closure will become evident much later than the immediate results of selection. As the closure of the biosphere takes place along with natural selection, whose direction is orthogonal to if not the opposite of that of biosphere closure, an extension to the name of this paradox suggests itself - the VernadskyDarwin paradox.

\section{Energy epochs of life on Earth}

To propose a possible solution to this paradox, let us consider the history of the origin of the terrestrial biosphere. Very many published studies have been devoted to reconstructions of the history of Earth's biosphere based on existing geological and paleontological data (Lazcano, Miller, 1996; Russell et al., 2010; Lane et al., 2010; Dibrova et al., 2012; Sousa et al., 2013; Weiss et al., 2016; Lanier, Williams, 2017; Russell, Hall, 
2006; Wächtershäuser, 2006; Kitadai, Maruyama, 2018; Amenabar, Boyd, 2019), and there is no sense in restating them here. One of the more interesting studies (Judson, 2017) divides the development of the biosphere into four epochs differing in the energy source available to living beings: 1) geochemical energy; 2) solar energy; 3) energy from oxidative phosphorylation; and 4) energy from the consumption of living flesh, or predation. We trace the history of the biosphere in the context of the formation of its closure, relating the change in the closure level to energy epochs. In what follows, all factual material without references will be taken from the previously mentioned work (Judson, 2017).

\section{The failure of the heterotrophic hypothesis of the origin of life}

The very first question is as follows: When did the biosphere appear, not as a place where living organisms exist, but rather as a system of interacting organisms, populations, and ecosystems? Most experts are inclined to believe that life on Earth originated under anaerobic conditions around the hydrothermal sources that supply energy for chemoautotrophic synthesis (Lazcano, Miller, 1996; Judson, 2017; Russell, Hall, 2006; Amenabar, Boyd, 2019). An alternative hypothesis, suggesting the heterotrophic nature of the first organisms, encounters a number of objections.

First, there are no data suggesting the presence of a very large amount of organic matter in the ocean of the ancient Earth (Lazcano, Miller, 1996).

Second, the organic broth resulting from abiogenic synthesis should be a very heterogeneous racemic mixture of various organic substances. The digestive system of modern heterotrophs is "tuned" to a highly specific type of organic matter (for example, proteins, fats, and carbohydrates). There are corresponding metabolic pathways for the consumption of these types of matter. The assumption that the primary organism contained an equally diverse set of metabolic pathways for utilizing organic matter in the broth seems improbable. If the organism had a limited number of metabolic pathways for utilizing the respective substrates, then because of the expected small amounts of these substrates, it would suffer a constant, acute, and possibly fatal nutrient deficiency.

Third, even if an ocean with organic substances did exist and primary organisms were able to utilize them, the solution to the task considered at the beginning of this paper suggests that they would be quickly consumed and that heterotrophic organisms would die out or their biomass growth would be terminated by an increase in the concentration of metabolites fermentation products.

In any case, if the heterotrophic hypothesis were valid, no closure of the matter flow would occur, and thus, there would be no biosphere as a system of interactions.

\section{Origin of life - no biosphere yet}

The scenario of chemoautotrophic generation of life (Lazcano, Miller, 1996; Judson, 2017; Russell, Hall, 2006; Amenabar, Boyd, 2019) suggests isolated oases of life around hydrothermal springs. There was virtually no interaction between them because of the limited availability of resources. The possibility for anoxygenic photosynthesis is not a significant factor, as there must be reduced substrates in the medium - hydrogen sulfide, thiosulfate, organic compounds, or molecular hydrogen - to perform it. Therefore, it could be carried out only around the sources of these substrates.

Thus, the origin of life does not mean the emergence of the biosphere as a system of interacting components. The level of closure of matter flows was globally minimal, and the 
conditions corresponding to the VernadskyDarwin paradox had not yet arisen.

\section{The Great Oxidation -}

\section{the birth of the biosphere}

The appearance of cyanobacteria, which are capable of oxygenic photosynthesis, dates to approximately 2.5 billion years ago. This event started the period called the Great Oxidation. The oxygen concentration began to rise from the initial $10^{-5}$-th fraction of the current atmospheric oxygen level, reaching $0.1-1 \%$ of the current level by $\sim 2$ billion years ago. However, a tricky question arises regarding the Great Oxidation. Genetic, fossil and geochemical data confirm that cyanobacteria appeared at least 300 million years before the Great Oxidation event. However, if cyanobacteria appeared hundreds of millions of years before the Great Oxidation event, why did the accumulation of oxygen take so long?

One hypothesis (Goldblatt et al., 2006) is that the oxygen released by cyanobacteria was associated with substances present in the atmosphere and in the ocean of early Earth (hydrogen, methane, and ferrous iron). However, as shown in the solutions of the school tasks above, if the growth of cyanobacteria had not been limited by any factor, the cyanobacteria would have quickly produced an amount of oxygen sufficient to oxidize all available oxidizable substances on Earth.

A better-substantiated hypothesis is that the growth rate of cyanobacteria was limited by a phosphorus deficiency (Kipp, Stüeken, 2017). Here, we have a very important factor for the closure of material flows - stoichiometric constraints. According to this hypothesis, phosphorus determines marine biological productivity on a geological time scale. The emergence of aerobic photosynthesis triggered rapid absorption of carbon dioxide and, hence, rapid biomass production. Due to the low oxygen concentration, the demineralization rate was insignificant, and deposition of dead biomass and the phosphorus contained therein occurred. However, despite the consistency and validity of the hypothesis, some ambiguities remain. For example, if the proposed scenario were true, after the appearance of cyanobacteria and the onset of photosynthesis, the phosphorus concentration should have dropped dramatically to almost zero, but no evidence of this drop has been presented.

Another explanation is that with the emergence of oxygenic photosynthesis, the need to develop protection against oxygen and its reactive species arose. In other words, the time interval between the appearance of cyanobacteria and the Great Oxidation event might have been associated with the need to create a system of protection against their own product. Each of the reasons listed above (and unknown ones as well) might have contributed to the delay.

As long as the transition processes associated with the global change in conditions on early Earth occurred, the level of closure of matter flows was close to zero. During the Great Oxidation, the biosphere was generated. The global change in atmospheric gas composition simultaneously influenced all organisms in contact with the atmosphere, and instead of separate and virtually noninteracting chemoautotrophic oases, an integrated ecological system developed. Of the four energy epochs of life on Earth mentioned above, the formation of the biosphere corresponds to the end of the second and beginning of the third energy epochs - the transition to oxidative phosphorylation.

During the Great Oxidation and the drop in carbon dioxide concentration from $\sim 7000 \mathrm{ppm}$ to $\sim 250 \mathrm{ppm}$ (at the end of the Paleozoic, the concentration increased approximately tenfold), approximately $20000 \mathrm{GtC}$ of organic residues was deposited. At the same time, the oxygen concentration in the atmosphere reached $\sim 2 \%$ 
of the current atmospheric concentration; in other words, it rose slightly above the Pasteur point, where oxidative phosphorylation became energetically favorable.

\section{Bacterial mats as local ecosystems - an "unconsolidated" biosphere}

Then, for 1.5 billion years, the oxygen concentration in Earth's atmosphere did not change, suggesting that the rate of photosynthesis and the mineralization of organic matter conducted by decomposers were precisely balanced. Since the atmospheric oxygen concentration was only slightly above Pasteur's point and there was no increased organic matter deposition, the elevated oxygen concentration was presumably created in the bulk of bacterial mats, ensuring rapid decomposition of dead biomass and a supply of mineral nutrients to phototrophs. This significantly accelerated cyclic processes, while minerals could still be assimilated from the environment. The specific growth rate of bacterial communities with a locally elevated oxygen concentration became higher, and they consumed external resources quicker, gaining a competitive advantage (Abed, 2010; Morris et al., 2008). The bacterial communities that enabled more rapid material cycling won.

At the same time, bacterial communities were rather highly closed systems, while the biosphere, despite the high overall balance of matter flows, was a system with weak global connections, i.e., not quite a system yet.

\section{Bacterial mats}

\section{and the Vernadsky-Darwin paradox}

Consider the possibility (conditions) of resolving the Vernadsky-Darwin paradox inside closed bacterial systems. To do this, we construct a model of such a system, taking into account the stoichiometric proportions of the two nutrients (for example, nitrogen and phosphorus) in the biomass of autotrophic and heterotrophic bacteria.

The growth rate of autotroph $X_{1}$ biomass is determined by the concentration of both nutrients $(A$ and $B$ ) in the environment, and it is described by the Mitscherlich formula (Mitscherlich, 1956). Since there are no predators yet, we introduce quadratic dependence of the extinction rate on the biomass concentration. The biomass dies and becomes detritus of two types, namely, $D_{A}$ and $D_{B}$, corresponding to the nutrients, which are then consumed by heterotroph $X_{2}$. The ratio of nutrients for each species is given by $\frac{a_{i}}{b_{i}}$. The heterotroph mineralizes detritus, first converting it into its own biomass and then lysing the biomass of dead heterotrophic bacteria. In addition, there are two nutrient conservation laws $\left(A_{0}\right.$ and $\left.B_{0}\right)$ in the system, which allow us to conceive two differential equations describing their dynamics:

$$
\left\{\begin{array}{l}
\text { 1) } \frac{d X_{1}}{d t}=\mu_{1} \frac{A B}{A B+K_{1}} X_{1}-m_{1} X_{1}^{2} \\
\text { 2) } \frac{d D_{A}}{d t}=a_{1} m_{1} X_{1}^{2}-\mu_{2} a_{2} \frac{D_{A} D_{B}}{D_{A} D_{B}+K_{2}} X_{2} \\
\text { 3) } \frac{d D_{B}}{d t}=b_{1} m_{1} X_{1}^{2}-\mu_{2} b_{2} \frac{D_{A} D_{B}}{D_{A} D_{B}+K_{2}} X_{2} \\
\text { 4) } \frac{d X_{2}}{d t}=\mu_{2} \frac{D_{A} D_{B}}{D_{A} D_{B}+K_{2}} X_{2}-m_{2} X_{2}^{2} \\
\text { 5) } A_{0}=A+a_{1} X_{1}+a_{2} X_{2} \\
\text { 6) } B_{0}=B+b_{1} X_{1}+b_{2} X_{2}
\end{array}\right.
$$

Let us estimate the conditions for the existence of the system stationary state. From Equation 4, we obtain:

$$
\mu_{2} \frac{D_{A} D_{B}}{D_{A} D_{B}+K_{2}}=m_{2} X_{2} .
$$

Substituting this expression into equations 2 and 3 and carrying out apparent simplifications, we obtain:

$$
\frac{a_{1}}{b_{1}}=\frac{a_{2}}{b_{2}} .
$$


This condition shows that a stationary state exists in the system only when the ratios of the nutrients in the biomasses of the autotroph and the decomposer coincide; in other words, these organisms must be genetically identical. It seems obvious that organisms with different functions cannot have identical structures and, hence, identical genetically determined elemental compositions.

One of the possible ways to resolve the Vernadsky-Darwin paradox at the level of a bacterial mat is to assume that the trophic level of decomposers consists of more than one species with different stoichiometric compositions. Let us determine which conditions the stoichiometric composition of decomposers should satisfy if there are two types of decomposers in a bacterial mat. Then, the model has the following form:

Having carried out simple calculations, we can see that in the steady state, the following relation should hold between the biomasses of decomposers:

$$
\begin{aligned}
& \text { (1) } \frac{d X_{1}}{d t}=\mu_{1} \frac{A B}{A B+K_{1}} X_{1}-m_{1} X_{1}^{2} \\
& \text { 2) } \frac{d D_{A}}{d t}=a_{1} m_{1} X_{1}^{2}-\mu_{2} a_{2} \frac{D_{A} D_{B}}{D_{A} D_{B}+K_{2}} X_{2}- \\
& -\mu_{3} a_{3} \frac{D_{A} D_{B}}{D_{A} D_{B}+K_{3}} X_{3} \\
& \text { 3) } \frac{d D_{B}}{d t}=b_{1} m_{1} X_{1}^{2}-\mu_{2} b_{2} \frac{D_{A} D_{B}}{D_{A} D_{B}+K_{2}} X_{2}- \\
& -\mu_{3} b_{3} \frac{D_{A} D_{B}}{D_{A} D_{B}+K_{3}} X_{3} \\
& \text { 4) } \frac{d X_{2}}{d t}=\mu_{2} \frac{D_{A} D_{B}}{D_{A} D_{B}+K_{2}} X_{2}-m_{2} X_{2}^{2} \\
& \text { 5) } \frac{d X_{3}}{d t}=\mu_{3} \frac{D_{A} D_{B}}{D_{A} D_{B}+K_{3}} X_{3}-m_{3} X_{3}^{2} \\
& \text { 6) } A_{0}=A+a_{1} X_{1}+a_{2} X_{2}+a_{3} X_{3} \\
& \text { 7) } B_{0}=B+b_{1} X_{1}+b_{2} X_{2}+b_{3} X_{3} \\
& X_{2}^{2}=X_{3}^{2} \frac{m_{3}}{m_{2}}\left(\frac{a_{3} b_{1}-a_{1} b_{3}}{a_{1} b_{2}-a_{2} b_{1}}\right) .
\end{aligned}
$$

For expression (6) to have meaning, the expression in parentheses must be positive. This requirement is satisfied if the ratios of the amounts of nutrients in the biomass of organisms satisfy the following ratios:

$$
\frac{a_{2}}{b_{2}}<\frac{a_{1}}{b_{1}}<\frac{a_{3}}{b_{3}} \quad \text { or } \quad \frac{a_{2}}{b_{2}}>\frac{a_{1}}{b_{1}}>\frac{a_{3}}{b_{3}} .
$$

Inequality relations usually occur in nature. Thus, a simple model suggests the hypothesis that in closed systems, the trophic level should always consist of several types. In this model, the number of different heterotrophs should be no fewer than the number of nutrients.

In the model of a bacterial mat, the Vernadsky-Darwin paradox can be resolved in another way - the system must contain two autotrophs and one heterotroph capable of selecting the prey, i.e., a predator (Saltykov et al., 2012). Therefore, we move to the fourth energy epoch of the development of life on Earth (Judson, 2017) - consumption of living flesh, or predation.

\section{The appearance of predators - the beginning of the transition to the "mature" biosphere}

The origin of predation approximately 570 million years ago was associated with the appearance of eukaryotes and their ability to phagocytize - to absorb particles and other forms of life. The acquisition of energy through active hunting, associated with the appearance of animals, led to a radical shift that transformed Earth in just 40 million years. The oxygen increase 550 million years ago (Lyons et al., 2014) almost coincided with the appearance of animals. It remains unclear whether the appearance of animals resulted from the increase in oxygen concentration and the increase in the efficiency of oxidative phosphorylation or, vice versa, the appearance of animals caused global changes in the composition of the atmosphere.

It is important that complex food networks with many types of consumers were absent on 
Earth until approximately 550 million years ago, when the first animals that eat animals appeared. It seems that their appearance led to the rapid diversification of animal life. In geological terms, the thriving of animals had at least four major impacts on the biosphere.

First, the evolution of predators quickly led to the development of armor - scales, thorns, and shells made of materials such as calcite and silica. This development ultimately led to extremely large deposits of materials such as radiolarian chert, limestone, shell rock and chalk as well as changes in ocean chemistry.

Second, animals produce feces, which has a significant effect on the way nutrients are distributed globally. For example, sperm whale feces transports iron from the deep sea to the upper layer of the ocean, and the feces of birds such as cormorants caries nutrients from the ocean to dry land, sometimes in substantial quantities.

The third geological impact of animals is associated with their ability to dig in. Simple horizontal holes appear in the fossil record approximately 555 Ma. Widespread digging creates the mixing of sediments, known as bioturbation: it redistributes nutrients and sifts, irrigates and aerates sediments and soil.

Finally, the fourth major impact of flesheating forms arises from bioturbation, feces and the evolution of armor: the reorganization of Earth's biogeochemical cycles (Canfield et al., 2006; Boyle et al., 2014; Logan et al., 1995).

\section{The Carboniferous period -} the transition to the modern state of the biosphere

The increase in the number of available energy sources led to the creation of a much more complex biosphere, in which the interactions between the components became very close. The last severe imbalance in matter flow occurred during the Carboniferous period, which ended 300 million years ago. The atmospheric oxygen concentration at that time reached $35 \%$, which is attributed to the appearance of lignin in land vegetation, which sharply lowered the decomposition rate of dead organic matter and contributed to the absorption of fallen plants by swamps and the subsequent formation of coal deposits.

The biosphere finally matured and became highly closed and systemic, in every sense, only 300 million years ago. The great diversity of organisms and the ramification of the food network of the biosphere facilitated the closure of matter flows and prevented the formation of so-called dead-locks, i.e., substances that are not consumed by other organisms. The fine adjustment of the food network could have occurred through adaptive metabolism, as discussed in a study by Saltykov et al. (2012), finally solving the Vernadsky-Darwin paradox.

\section{Conclusion}

When we consider the biosphere as a system of interacting components - populations and local ecosystems - we should recognize that the origin of life on ancient Earth did not mean the origin of the biosphere. The biosphere was born during the stage of photosynthesis emergence, when living beings began to have a global impact on each other. A full-fledged "mature" biosphere - a system with intense interactions between components did not form until 300 million years ago. At the same time, high closure of matter flows resulted from the formation of an extensive network of trophic interactions and metabolic flexibility of individuals. 


\section{References}

Abed R.M.M. (2010) Interaction between cyanobacteria and aerobic heterotrophic bacteria in the degradation of hydrocarbons. International Biodeterioration \& Biodegradation, 64(1): 58-64

Amenabar M.J., Boyd E.S. (2019) A review of the mechanisms of mineral-based metabolism in early Earth analog rock-hosted hydrothermal ecosystems. World Journal of Microbiology and Biotechnology, 35(2): 29

Barlow C., Volk T. (1990) Open systems living in a closed biosphere: a new paradox for the Gaia debate. BioSystems, 23(4): 371-384

Boyle R.A., Dahl T.W., Dale A.W., Shields-Zhou G.A., Zhu M., Brasier M.D., Canfield D.E., Lenton T.M. (2014) Stabilization of the coupled oxygen and phosphorus cycles by the evolution of bioturbation. Nature Geoscience, 7(9): 671-676

Brovkin V., Sitch S., von Bloh W., Claussen M., Bauer E., Cramer W. (2004) Role of land cover changes for atmospheric $\mathrm{CO} 2$ increase and climate change during the last 150 years. Global Change Biology, 10(8): 1253-1266

Canfield D.E., Rosing M.T., Bjerrum C. (2006) Early anaerobic metabolisms. Philosophical Transactions of the Royal Society B-Biological Sciences, 361(1474): 1819-1836

IPCC (2007) Climate Change 2007: The Physical Science Basis. Contribution of Working Group I to the Fourth Assessment Report of the Intergovernmental Panel on Climate Change (Solomon S., Qin D., Manning M., Chen Z., Marquis M., Averyt K.B., Tignor M., Miller H.L. (eds.) Cambridge University Press, Cambridge, United Kingdom and New York, NY, USA, 996 p.

Dibrova D.V., Chudetsky M.Y., Galperin M.Y., Koonin E.V., Mulkidjanian A.Y. (2012) The role of energy in the emergence of biology from chemistry. Origins of Life and Evolution of Biospheres, 42(5): 459-468

Goldblatt C., Lenton T.M., Watson A.J. (2006) Bistability of atmospheric oxygen and the Great Oxidation. Nature, 443(7112): 683-686

Judson O.P. (2017) The energy expansions of evolution. Nature Ecology \& Evolution, 1(6): UNSP 0138

Kipp M.A., Stüeken E.E. (2017) Biomass recycling and Earth's early phosphorus cycle. Science Advances, 3(11): eaao4795

Kitadai N., Maruyama S. (2018) Origins of building blocks of life: A review. Geoscience Frontiers, 9(4): 1117-1153

Lane N., Allen J.F., Martin W. (2010) How did LUCA make a living? Chemiosmosis in the origin of life. BioEssays, 32(4): 271-280

Lanier K.A., Williams L.D. (2017) The origin of life: models and data. Journal of Molecular Evolution, 84(2-3): 85-92

Lazcano A., Miller S.L. (1996) The origin and early evolution of life: prebiotic chemistry, the preRNA world, and time. Cell, 85(6): 793-798

Logan G.A., Hayes J.M., Hieshima G.B., Summons R.E.(1995) Terminal Proterozoic reorganization of biogeochemical cycles. Nature, 376(6535): 53-56

Lyons T.W., Reinhard C.T., Planavsky N.J. (2014) The rise of oxygen in Earth's early ocean and atmosphere. Nature, 506(7488): 307-315

Mitscherlich E.A. (1956) Yield laws. Berlin, Akademie-Verlag, 75 p. (in German)

$$
\text { - } 346-
$$


Morris J.J., Kirkegaard R., Szul M.J., Johnson Z.I., Zinser E.R. (2008) Facilitation of robust growth of Prochlorococcus colonies and dilute liquid cultures by 'helper' heterotrophic bacteria. Applied and Environmental Microbiology, 74(14): 4530-4534

Petit J.R., Jouzel J., Raynaud D., Barkov N.I., Barnola J.-M., Basile I., Bender M., Chappellaz J., Davis M., Delaygue G., Delmotte M., Kotlyakov V.M., Legrand M., Lipenkov V.Y., Lorius C., Pepin L., Ritz C., Saltzman E., Stievenard M. (1999) Climate and atmospheric history of the past 420,000 years from the Vostok ice core, Antarctica. Nature, 399 (6735): 429-436

Russell M.J., Hall A.J. (2006) The onset and early evolution of life. Evolution of early Earth's atmosphere, hydrosphere, and biosphere - constraints from ore deposits: Geological Society of America Memoir 198. Kesler S.E., Ohmoto H. (eds.) Geological Society of America, p. 1-32

Russell M.J., Hall A.J., Martin W. (2010) Serpentinization as a source of energy at the origin of life. Geobiology, 8(5): 355-371

Saltykov M.Yu., Bartsev S.I., Lankin Yu.P. (2012) Stability of Closed Ecology Life Support Systems (CELSS) models as dependent upon the properties of metabolism of the described species. Advances in Space Research, 49(2): 223-229

Sousa F.L., Thiergart T., Landan G., Nelson-Sathi S., Pereira I.A.C., Allen J.F., Lane N., Martin W.F. (2013) Early bioenergetic evolution. Philosophical Transactions of the Royal Society B-Biological Sciences, 368(1622): 20130088

Stainforth D.A., Aina T., Christensen C., Collins M., Faull N., Frame D.J., Kettleborough J.A., Knight S., Martin A., Murphy J.M., Piani C., Sexton D., Smith L.A., Spicer R.A., Thorpe A.J., Allen M.R. (2005) Uncertainty in predictions of the climate response to rising levels of greenhouse gases. Nature, 433(7024): 403-406

Wächtershäuser G. (2006) From volcanic origins of chemoautotrophic life to Bacteria, Archaea and Eukarya. Philosophical Transactions of the Royal Society B-Biological Sciences, 361(1474): 17871808

Weiss M.C., Sousa F.L., Mrnjavac N., Neukirchen S., Roettger M., Nelson-Sathi S., Martin W.F. (2016) The physiology and habitat of the last universal common ancestor. Nature Microbiology, 1(9): 16116 